\title{
EKSPERIMENTASI MODEL PEMBELAJARAN KOOPERATIF TIPE THINK PAIR SHARE (TPS) DENGAN PENDEKATAN OPEN-ENDED DITINJAU DARI DISPOSISI MATEMATIS SISWA KELAS VIII SMP NEGERI DI KABUPATEN PURWOREJO
}

\author{
Zainnur Wijayanto \\ Pendidikan Matematika, FKIP, Universitas Sarjanawiyata Tamansiswa \\ Email: zannuwijaya@yahoo.com
}

\begin{abstract}
Abstrak
Tujuan penelitian ini adalah untuk mengetahui : 1) manakah yang mempunyai prestasi belajar matematika lebih baik, siswa yang dikenai model pembelajaran kooperatif tipe Think Pair Share (TPS) dengan pendekatan open-ended atau pembelajaran langsung, 2) manakah yang mempunyai prestasi belajar matematika lebih baik, siswa yang memiliki disposisi matematis tinggi, sedang, atau rendah, 3) pada masing-masing model pembelajaran, manakah yang mempunyai prestasi belajar matematika lebih baik, siswa dengan disposisi matematis tinggi, sedang, atau rendah, 4) pada masing-masing kategori disposisi matematis, manakah yang mempunyai prestasi belajar matematika lebih baik, siswa yang dikenai model pembelajaran kooperatif tipe TPS dengan pendekatan openended atau pembelajaran langsung. Penelitian ini merupakan penelitian eksperimental semu. Populasi penelitian ini adalah siswa kelas VIII SMP Negeri di Kabupaten Purworejo tahun ajaran 2013/2014. Sampel dalam penelitian ini adalah siswa SMPN 20 Purworejo, SMPN 14 Purworejo, SMPN 13 Purworejo yang diambil secara stratified cluster random sampling. Instrumen yang digunakan untuk mengumpulkan data adalah instrumen tes prestasi belajar matematika, instrumen angket disposisi matematis siswa. Teknik analisis data yang digunakan adalah uji hipotesis menggunakan anava dua jalan dengan sel tak sama. Dari hasil analisis disimpulkan bahwa : 1) prestasi belajar matematika siswa yang diberi pembelajaran dengan model pembelajaran kooperatif tipe TPS dengan pendekatan open-ended lebih baik daripada siswa yang diberi pembelajaran langsung, 2) prestasi belajar matematika siswa dengan disposisi matematis tinggi lebih baik daripada siswa dengan disposisi matematis sedang dan rendah, begitu juga dengan prestasi belajar matematika siswa dengan disposisi matematis sedang lebih baik daripada siswa dengan disposisi matematis rendah, 3) pada model pembelajaran kooperatif tipe TPS dengan pendekatan open-ended prestasi belajar matematika siswa yang memiliki disposisi matematis tinggi lebih baik daripada siswa yang memiliki disposisi matematis sedang maupun rendah. Pada pembelajaran langsung, siswa dengan disposisi matematis tinggi memiliki prestasi belajar yang lebih baik daripada siswa yang memiliki disposisi matematis sedang dan rendah, siswa dengan disposisi matematis sedang memiliki prestasi belajar yang sama dengan siswa yang memiliki disposisi matematis rendah, 4) Pada siswa dengan disposisi matematis tinggi, siswa dengan disposisi matematis sedang dan siswa dengan disposisi matematis rendah memiliki prestasi belajar yang sama antara siswa yang dikenai model pembelajaran kooperatif tipe TPS dengan pendekatan open-ended dan pembelajaran langsung.
\end{abstract}

Kata Kunci: Think Pair Share (TPS), Pendekatan Open-Ended, Pembelajaran Langsung, Disposisi Matematis 


\section{PENDAHULUAN}

Matematika merupakan ilmu dalam belajar matematika. Peker (2008) universal yang mendasari perkembangan teknologi modern sehingga mempunyai peran penting dalam berbagai disiplin ilmu dan mengembangkan daya pikir manusia. Matematika perlu diberikan kepada semua peserta didik mulai dari sekolah dasar sampai perguruan tinggi untuk membekali peserta didik dengan kemampuan berpikir logis, analitis, sistematis, kritis, dan kreatif, serta kemampuan bekerja sama (Permendiknas, 2006). Pada kenyataannya mutu pendidikan matematika di Indonesia masih rendah dibandingkan dengan mutu pendidikan matematika negara-negara lain. Hal ini setidaknya tercermin dari hasil tes Trends in International Mathematics and Sciences Study (TIMSS) yang diikuti oleh siswa kelas VIII SMP. Hasil evaluasi TIMSS 2011 untuk matematika kelas VIII, Indonesia pada posisi 5 besar dari bawah (bersama Syria, Moroko, Oman, Ghana).

Salah satu faktor penyebabnya adalah cara guru dalam pengelolaan pembelajaran di kelas. Penelitian yang dilakukan Akinsola dan Olowojaiye (2008) menyimpulkan bahwa cara guru dalam penyampaian pembelajaran di kelas sangat berpengaruh dalam mengubah sikap dan kebiasaan siswa mengatakan bahwa 'Students' low success level in mathematics has been a worry for a long time in many countries. There are a lot of factors affecting success in mathematics. One of these factors is students' mathematical anxiety, in other words, their mathematicalfear".

Untuk menjawab permasalahan tersebut salah satunya dengan menggunakan model pembelajaran yang dapat memperbaiki dan meningkatkan mutu proses belajar mengajar. Menurut George (2010), model pembelajaran yang terbukti dapat meningkatkan proses belajar mengajar adalah model pembelajaran kooperatif. Hasil penelitian dari Zakaria (2010) juga menyatakan, "The cooperative learning methods improve students' achievement in mathematics and attitude towards mathematics" mengungkapkan bahwa pembelajaran kooperatif dapat meningkatkan prestasi belajar dan sikap siswa terhadap matematika.

Salah satu model pembelajaran kooperatif yang efektif dan mudah diterapkan adalah model pembelajaran kooperatif tipe Think Pair Share (TPS) yang dikembangkan oleh F. Lyman pada tahun 1985 dari Universitas Maryland. Think Paire Share merupakan salah satu 
model pembelajaran kooperatif sederhana yang memberi kesempatan pada siswa untuk bekerja sendiri serta bekerja sama dengan orang lain. Keunggulan model pembelajaran ini, yaitu mampu mengoptimalkan partisipasi siswa (Anita Lie, 2004:57). Penelitian yang dilakukan oleh Bowering et al (2007) mengungkapkan bahwa model pembelajaran TPS memberi pengaruh yang positif sehingga menimbulkan prestasi yang baik. Danebeth (2012) dalam penelitiannya menyimpulkan bahwa penerapan model pembelajaran kooperatif tipe TPS memberikan pengaruh yang signifikan terhadap kinerja kelompok dalam pembelajaran jika dibandingkan dengan pembelajaran konvensional.

Menurut Alfiyatul Fajar (2010), dalam penelitiannya ditemukan bahwa terdapat kelemahan pada model pembelajaran Think Pair Share (TPS) yang akhirnya menjadi kendala dalam penggunaan model pembelajaran ini, diantaranya adalah siswa yang pandai cenderung mendominasi sehingga dapat menimbulkan sikap minder dan pasif dari siswa yang berkemampuan rendah, diskusi tidak akan berjalan lancar jika siswa hanya menyalin pekerjaan siswa yang pandai tanpa memahami bagaimana proses menyelesaikan pekerjaan/ tugas yang diberikan. Hal yang senada juga diungkapkan oleh Anita Lie (2004: 46), kekurangan dari kelompok berpasangan (kelompok yang terdiri dari 2 orang siswa) salah satunya adalah lebih sedikit ide yang muncul.

Menurut Shimada \& Becker (1997), pendekatan open-ended adalah pembelajaran yang menyajikan suatu permasalahan yang memiliki metode atau penyelesaian yang benar lebih dari satu. Hal ini sejalan dengan pendapat Hollingworth, Beard, \& Proctor (2007) yang mengatakan bahwa pokok pikiran dari pembelajaran dengan open-ended yaitu pembelajaran yang membangun kegiatan interaktif antara matematika dan siswa sehingga mengundang siswa untuk menjawab permasalahan melalui berbagai strategi. Pendekatan openended dapat memberi kesempatan kepada siswa untuk memperoleh pengetahuan/ pengalaman menemukan, mengenali, dan memecahkan masalah dengan beragam teknik.

Salah satu faktor yang mempengaruhi proses dan hasil belajar matematika siswa adalah disposisi mereka terhadap matematika. Damon (2005) dalam penelitiannya juga menyimpulkan bahwa disposisi mempunyai pengaruh yang besar terhadap proses pembelajaran. Disposisi matematis adalah keinginan, kesadaran, dan dedikasi yang kuat pada diri siswa 
untuk belajar matematika dan lebih baik, siswa dengan disposisi melaksanakan berbagai kegiatan matematis tinggi, sedang, atau rendah, 3) matematika (Sumarmo, 2006).

Berdasarkan uraian yang pada masing-masing kategori disposisi dikemukakan di atas, tujuan dalam penelitian ini adalah untuk mengetahui: 1) manakah yang memberikan prestasi belajar matematika lebih baik diantara model pembelajaran kooperatif tipe Think Pair Share (TPS) dengan pendekatan open-ended atau pembelajaran langsung, 2) manakah yang mempunyai prestasi belajar matematika

\section{METODE PENELITIAN}

Penelitian ini merupakan penelitian eksperimental semu dengan menggunakan rancangan faktorial $2 \times 3$. Populasinya adalah seluruh siswa kelas VIII SMP Negeri di Kabupaten Purworejo, dan sampelnya diambil dengan teknik stratified cluster random sampling. Penelitian dilakukan di SMP Negeri 13 Purworejo, SMP Negeri 14 Purworejo, SMP Negeri 20 yang masingmasing diambil satu kelas eksperimen dan satu kelas kontrol. Sampel dalam penelitian ini berjumlah 190 siswa yang terdiri dari 96 siswa pada kelas eksperimen dan 94 siswa pada kelas kontrol. Dalam penelitian ini terdapat dua variabel bebas yaitu model pembelajaran dan disposisi matematis siswa dan satu variabel terikat yaitu prestasi belajar matematika. prestasi belajar matematika lebih baik diantara model pembelajaran kooperatif tipe TPS dengan pendekatan open-ended atau pembelajaran langsung, 4) pada masing-masing model pembelajaran, manakah yang mempunyai prestasi belajar matematika lebih baik, siswa dengan disposisi matematis tinggi, sedang, atau rendah.

Teknik pengumpulan data menggunakan metode dokumentasi, tes dan angket. Metode dokumentasi digunakan untuk mengumpulkan data kemampuan awal siswa, metode tes digunakan untuk mengumpulkan data prestasi belajar matematika, dan metode angket digunakan untuk mengumpulkan data disposisi matematis siswa. Instrumen yang digunakan dalam penelitian ini berupa tes objektif bentuk pilihan ganda pada materi bangun ruang sisi datar dan angket disposisi matematis untuk membedakan disposisi matematis dalam kategori tinggi, sedang atau rendah.

Uji coba instrumen dilakukan di SMP Negeri 18 dan SMP Negeri 32 Purworejo dengan responden 69 siswa. Untuk instrumen tes prestasi belajar, 
mengacu pada kriteria yaitu validitas isi, daya pembeda $(\mathrm{D} \geq 0,3)$, tingkat kesukaran $(0,3 \leq \mathrm{P} \leq 0,7)$ dan reliabilitas $\left(r_{11} \geq 0,7\right)$, dari 40 butir soal yang diujicobakan diperoleh 25 butir soal yang digunakan sebagai alat pengambil data prestasi belajar matematika siswa. Uji coba angket disposisi matematis, mengacu pada kriteria yaitu validitas isi, konsistensi internal ( $\mathrm{D} \geq 0,3)$ dan

\section{HASIL PENELITIAN DAN}

\section{PEMBAHASAN}

Sebelum dilakukan eksperimen sampel harus dalam keadaan seimbang. Data yang digunakan sebagai uji keseimbangan adalah data dokumentasi nilai Ujian Akhir Sekolah (UAS) matematika semester 1. Untuk selanjutnya dilakukan uji normalitas, uji homogenitas dan uji keseimbangan pada data tersebut. Berdasarkan uji normalitas dengan menggunakan metode Lilliefors diperoleh harga statistik uji untuk taraf sigifikansi 0,05 pada kelas eksperimen didapatkan $\mathrm{L}_{\mathrm{obs}}=0,0792$ dan $\mathrm{L}_{0,05 ; 96}=$ 0,0904 dan kelas kontrol $\mathrm{L}_{\mathrm{obs}}=0,0774$ dan $\mathrm{L}_{0,05 ; 86}=0,0914$, pada masing-masing sampel nilai $\mathrm{L}_{\mathrm{obs}}<\mathrm{L}_{0,05 ; \mathrm{n}}$ dengan $D K=$ $\left\{L \quad \mid L>L_{\alpha ; n}\right\}$, sehingga $L_{o b s} \notin D K$ maka $H_{0}$ diterima artinya masingmasing sampel berasal dari populasi yang berdistribusi normal.

Hasil analisis uji homogenitas reliabilitas $\left(r_{11} \geq 0,7\right)$, dari 60 butir pernyataan yang diujicobakan diperoleh 40 butir pertanyaan sebagai alat pengambil data disposisi matematis siswa. Uji prasyarat analisis yaitu uji normalitas dengan Lilliefors dan uji homogenitas dengan uji Bartlett. Uji analisis data yang digunakan yaitu analisis variansi dua jalan dengan sel tak sama.

menggunakan uji Bartlett dengan statistik uji Chi-Kuadrat pada tingkat signifikansi 0,05 diperoleh hasil $\chi_{o b s}^{2}=2,211$ dengan $\chi_{0,05 ; 1}^{2}=3,841$ berarti harga dari $\chi_{o b s}^{2}<\chi_{0,05 ; 1}^{2}$ dengan $D K=\left\{\chi^{2} \mid \chi^{2}>\right.$ $\left.\chi_{0,05 ; 1}^{2}\right\}$, sehingga $\chi_{o b s}^{2} \notin D K$ maka $H_{0}$ diterima. Artinya bahwa sampel berasal dari populasi yang mempunyai variansi homogen.

Berdasarkan uji keseimbangan menggunakan anava satu jalan sel tak sama dengan taraf signifikansi 0,05 diperoleh hasil $\mathrm{F}_{\mathrm{obs}}=1,214$ dengan $\mathrm{F}_{0,05 ; 1,188}=3,89$. Karena $\mathrm{F}_{\mathrm{obs}}<\mathrm{F}_{0,05 ; 1,188}$

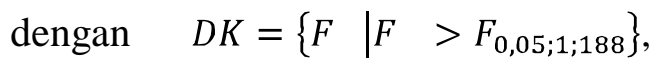
sehingga $F_{o b s} \notin D K$ maka $H_{0}$ diterima berarti populasi dalam keadaan seimbang.

Sebelum dilakukan analisis variansi dua jalan, terlebih dahulu dilakukan uji normalitas dan uji 
homogenitas sebagai uji prasyarat normalitas dan homogenitas disajikan analisis variansi. Rangkuman uji dalam Tabel 1 dan Tabel 2.

Tabel 1. Rangkuman hasil uji normalitas

\begin{tabular}{lcccc}
\hline \multicolumn{1}{c}{ Uji Normalitas } & $\mathbf{L}_{\text {obs }}$ & $\mathbf{L}_{\mathbf{0 , 0 5} ; \mathbf{n}}$ & Keputusan & Kesimpulan \\
\hline TPS Open-Ended & 0,0688 & 0,0904 & $\mathrm{H}_{0}$ diterima & Normal \\
Langsung & 0,0700 & 0,0914 & $\mathrm{H}_{0}$ diterima & Normal \\
Disposisi Tinggi & 0,0861 & 0,0934 & $\mathrm{H}_{0}$ diterima & Normal \\
Disposisi Sedang & 0,0820 & 0,0830 & $\mathrm{H}_{0}$ diterima & Normal \\
Disposisi Rendah & 0,0890 & 0,0967 & $\mathrm{H}_{0}$ diterima & Normal \\
\hline
\end{tabular}

Tabel 2. Rangkuman uji homogenitas

\begin{tabular}{lccccc}
\hline \multicolumn{1}{c}{ Sampel } & K & $\chi_{\text {obs }}^{\mathbf{2}}$ & $\chi_{\mathbf{0}, \mathbf{0 5} ; \boldsymbol{k}-\mathbf{1})}^{\mathbf{2}}$ & Keputusan & Kesimpulan \\
\hline Model & 2 & 2,657 & 3,841 & $\mathrm{H}_{0}$ diterima & Homogen \\
Pembelajaran & 3 & 1,701 & 5,991 & $\mathrm{H}_{0}$ diterima & Homogen \\
Disposisi Matematis siswa & & &
\end{tabular}

Berdasarkan Tabel 1 dan Tabel 2, jalan dengan sel tak sama dapat dapat diketahui bahwa sampel berasal dilakukan.

dari populasi yang berdistribusi normal Rerata prestasi belajar dan mempunyai variansi yang homogen matematika kelompok eksperimen dan dengan demikian uji hipotesis kelompok kontrol dapat dilihat dalam menggunakan teknik analisis variansi dua tabel 3.

Tabel 3. Rerata masing-masing sel dari data model pembelajaran dan disposisi matematis.

\begin{tabular}{lcccc}
\hline \multirow{2}{*}{ Model Pembelajaran } & \multicolumn{3}{c}{ Disposisi Matematis Siswa } & \\
\cline { 2 - 4 } & Tinggi & Sedang & Rendah & Rerata Marginal \\
TPS-Open Ended & 91,44 & 77,00 & 61,92 & 79,54 \\
Pembelajaran Langsung & 83,45 & 70,16 & 65,94 & 71,70 \\
Rerata Marginal & 88,74 & 73,11 & 64,27 & \\
\hline
\end{tabular}

Hasil perhitungan analisis variansi dua jalan sel tak sama dengan tingkat signifikansi 0,05 disajikan dalam Tabel 4.

Tabel 4. Rangkuman analisis variansi dua jalan

\begin{tabular}{ccccccc}
\hline Sumber & JK & dk & RK & $\boldsymbol{F}_{\text {obs }}$ & $\boldsymbol{F}_{\boldsymbol{\alpha}}$ & Keputusan \\
\hline Model Pembelajaran (A) & 437,86 & 1 & 245,74 & 8,02 & 3,89 & $\mathrm{H}_{0}$ ditolak \\
Disposisi Matematis & 4765,52 & 2 & 2382,76 & 40,31 & 3,05 & $\mathrm{H}_{0}$ ditolak \\
Interaksi (AB) & 1074,76 & 2 & 537,38 & 9,09 & 3,05 & $\mathrm{H}_{0}$ ditolak \\
Galat & 10876,35 & 184 & 59,11 & - & - & - \\
Total & 17190,49 & 189 & - & - & - & - \\
\hline
\end{tabular}

Kesimpulan analisis variansi dua jalan dengan sel tak sama berdasarkan
Tabel 4. adalah: (1) pada efek utama antar baris (A), siswa-siswa yang dikenai 
dengan model pembelajaran kooperatif TPS dengan open-ended dan pembelajaran langsung mempunyai prestasi belajar matematika yang berbeda. (2) pada efek utama antar kolom (B), ketiga disposisi matematis siswa memberikan efek yang berbeda terhadap prestasi belajar. (3) pada efek interaksi $(\mathrm{AB})$, terdapat interaksi antara model pembelajaran yang digunakan dan disposisi matematis siswa terhadap prestasi belajar matematika.

Berdasarkan anava dua jalan diperoleh bahwa $\mathrm{H}_{0 \mathrm{~A}}$ ditolak, sehingga perlu dilakukan uji lanjut pasca analisis variansi dengan metode Scheffe' untuk uji komparasi antar baris.

Tabel 5. Rangkuman hasil uji komparasi ganda antar baris

\begin{tabular}{cccccc}
\hline Komparasi & $\mathbf{H}_{\mathbf{0}}$ & $\mathbf{H}_{\mathbf{1}}$ & $\mathbf{F}_{\text {obs }}$ & $\mathbf{2 F}_{\mathbf{0}, \mathbf{0 5} ; \mathbf{2} ; \mathbf{2 7 6}}$ & Keputusan \\
\hline$\mu_{1 .}$ vs $\mu_{2 .}$ & $\mu_{1 .}=\mu_{3 .}$ & $\mu_{1 .} \neq \mu_{3 .}$ & 49,38 & 7,78 & $H_{0}$ ditolak \\
\hline
\end{tabular}

Berdasarkan Tabel 5. hasil uji komparasi antar baris pada masingmasing kategori model pembelajaran dan dengan melihat rerata marginalnya, diperoleh simpulan bahwa model pembelajaran kooperatif tipe TPS dengan pendekatan open-ended memberikan prestasi belajar matematika yang lebih baik dibandingkan pembelajaran langsung. Kesimpulan ini didukung oleh hasil penelitian Mella Yuliani (2013) yang dalam penelitiannya menyimpulkan prestasi belajar matematika peserta didik yang dikenai model pembelajaran kooperatif STAD dengan pendekatan open-ended pada pokok bahasan logaritma lebih baik daripada peserta didik yang dikenai model pembelajaran STAD. Kemudian menurut Hollingworth, Beard, \& Proctor (2007) yang mengatakan bahwa pokok pikiran dari pembelajaran dengan open-ended yaitu pembelajaran yang membangun kegiatan interaktif antara matematika dan siswa sehingga mengundang siswa untuk menjawab permasalahan melalui berbagai strategi. Diperkuat oleh Nohda (2000) yang mengemukakan bahwa dengan pendekatan open-ended guru berpeluang untuk membantu siswa dalam memahami dan mengelaborasi ide-ide matematika siswa sejauh dan sedalam mungkin. Di lain pihak, prestasi belajar matematika peserta didik yang dikenai model pembelajaran langsung, proses pembelajaran terpusat pada guru guru yang menyebabkan siswa menjadi pasif. Dengan demikian, pemahaman materi pokok bangun ruang sisi datar yang dikenai pembelajaran langsung lebih rendah dari dari pada peserta didik yang dikenai model pembelajaran kooperatif tipe TPS dengan pendekatan open-ended. Alasan ini kemudian diperkuat dengan 
penelitian yang dilakukan oleh Ofodu dan Raheem (2011) yang menyimpulkan bahwa pembelajaran matematika dengan menggunakan model pembelajaran TPS memberikan prestasi belajar yang lebih baik daripada model pembelajaran konvensional.

Berdasarkan anava dua jalan diperoleh bahwa $\mathrm{H}_{0 \mathrm{~B}}$ ditolak, sehingga perlu dilakukan uji lanjut pasca analisis variansi dengan metode Scheffe' untuk uji komparasi antar kolom.

Tabel 6. Rangkuman hasil uji komparasi ganda antar kolom

\begin{tabular}{cccccc}
\hline Komparasi & $\mathbf{H}_{\mathbf{0}}$ & $\mathbf{H}_{\mathbf{1}}$ & $\mathbf{F}_{\text {obs }}$ & $\mathbf{2 F}_{\mathbf{0}, \mathbf{0 5} ; \mathbf{2} ; \mathbf{2 7 6}}$ & Keputusan \\
\hline$\mu_{.1}$ vs $\mu_{.2}$ & $\mu_{.1}=\mu_{.2}$ & $\mu_{.1} \neq \mu_{.2}$ & 195,14 & 6,10 & $H_{0}$ ditolak \\
$\mu_{.2}$ vs $\mu_{.3}$ & $\mu_{.2}=\mu_{.3}$ & $\mu_{.2} \neq \mu_{.3}$ & 63,79 & 6,10 & $H_{0}$ ditolak \\
$\mu_{.1}$ vs $\mu_{.3}$ & $\mu_{.1}=\mu_{.3}$ & $\mu_{.1} \neq \mu_{.3}$ & 475,89 & 6,10 & $H_{0}$ ditolak \\
\hline
\end{tabular}

Berdasarkan Tabel 6. hasil uji komparasi antar kolom pada masingmasing kategori disposisi matematis dan dengan melihat rerata marginalnya, diperoleh simpulan bahwa siswa dengan disposisi matematis tinggi mempunyai prestasi belajar lebih baik dibandingkan siswa dengan disposisi matematis sedang dan rendah, dan siswa dengan disposisi matematis sedang mempunyai prestasi belajar lebih baik dibandingkan siswa dengan disposisi matematis rendah. Hasil ini sesuai dengan hipotesis penelitian. Hal ini dikarenakan siswa yang memiliki disposisi matematis tinggi dalam belajar matematika akan lebih percaya diri dengan kemampuannya, dapat mengeksplorasi ide-ide matematis dan mencoba berbagai metode untuk memecahkan masalah, bertekad yang kuat, ketertarikan dan keingintahuan menemukan sesuatu yang baru serta kecenderungan untuk merefleksi proses berpikir. Sehingga tujuan belajar tercapai dan menghasilkan prestasi belajar yang lebih baik. Pendapat tersebut juga diperkuat oleh Mutia (2013) yang dalam penelitiannya menyimpulkan bahwa siswa dengan disposisi tinggi mempunyai prestasi belajar yang lebih baik dari siswa dengan disposisi matematis sedang maupun rendah.

Berdasarkan analisis variansi dua jalan diperoleh bahwa $\mathrm{H}_{0 \mathrm{AB}}$ ditolak, sehingga perlu dilakukan uji lanjut pasca analisis variansi dengan metode Scheffe' untuk uji komparasi antar sel pada masing-masing kategori model pembelajaran dan disposisi matematis. Hasil uji komparasi ganda antar sel pada baris yang sama dideskripsikan sebagai berikut: 1) Pada model pembelajaran kooperatif tipe TPS dengan open-ended, siswa dengan disposisi matematis tinggi akan mencapai prestasi belajar yang lebih baik daripada siswa dengan disposisi 
matematis sedang maupun rendah. Hal ini dikarenakan model pembelajaran kooperatif TPS dengan pendekatan openended merupakan model pembelajaran konstruktivisme yang menuntut peran aktif siswa dalam kegiatan pembelajaran, oleh karena itu siswa dengan disposisi matematis tinggi akan cenderung lebih aktif baik dalam proses pembelajaran sehingga hasil yang dicapai juga lebih optimal. 3) Pada model pembelajaran langsung siswa dengan disposisi tinggi mempunyai prestasi belajar lebih baik daripada siswa dengan disposisi rendah, sedangkan siswa yang memiliki disposisi matematis sedang akan mencapai prestasi belajar yang sama dengan siswa yang memiliki disposisi matematis rendah.

Hasil uji komparasi ganda antar sel pada kolom yang sama dideskripsikan sebagai berikut: 1) Pada siswa dengan disposisi matematis tinggi, prestasi belajar matematika siswa yang dikenai model pembelajaran kooperatif TPS dengan open-ended sama baiknya dengan siswa yang dikenai pembelajaran langsung. Hal ini dikarenakan siswa yang memiliki disposisi matematis tinggi dalam belajar matematika akan lebih percaya diri dengan kemampuannya, dapat mengeksplorasi ide-ide matematis dan mencoba berbagai metode untuk memecahkan masalah, bertekad yang kuat, ketertarikan dan keingintahuan menemukan sesuatu yang baru serta kecenderungan untuk merefleksi proses berpikir. Sehingga siswa dengan disposisi matematis tinggi akan memperoleh informasi dalam jumlah yang sama banyak selama proses belajar sehingga memberikan prestasi belajar yang sama baiknya. 2) Pada siswa dengan disposisi matematis sedang, prestasi belajar matematika siswa yang dikenai model pembelajaran kooperatif TPS dengan open-ended sama baiknya dengan siswa yang dikenai pembelajaran langsung. 3) Pada siswa dengan disposisi matematis rendah, prestasi belajar matematika siswa yang dikenai model pembelajaran kooperatif TPS dengan open-ended sama baiknya dengan siswa yang dikenai pembelajaran langsung. Hasil ini tidak sesuai dengan hipotesis penelitian. Ketidaksesuaian hasil penelitian ini dimungkinkan karena siswa dengan disposisi matematis rendah cenderung tidak bersemangat dan tidak aktif dalam mengikuti proses belajar sehingga pemahaman siswa terhadap materi bangun ruang sisi datar menjadi kurang. Dengan demikian, pada disposisi matematis rendah, peneliti tidak mampu menjamin terjadinya interaksi antara siswa yang dikenai model pembelajaran kooperatif tipe TPS dengan open-ended, TPS dan model pembelajaran langsung. 


\section{SIMPULAN DAN SARAN}

Berdasarkan hasil penelitian dapat disimpulkan sebagai berikut. 1) Model pembelajaran kooperatif tipe TPS dengan pendekatan open-ended memberikan prestasi belajar yang lebih baik dibandingkan pembelajaran langsung. 2) Siswa dengan disposisi matematis tinggi mempunyai prestasi belajar lebih baik dibandingkan siswa dengan disposisi matematis sedang dan rendah, dan siswa dengan disposisi matematis sedang mempunyai prestasi belajar lebih baik dibandingkan siswa dengan disposisi matematis rendah. 3) Pada model pembelajaran kooperatif tipe TPS dengan pendekatan open-ended siswa dengan disposisi matematis tinggi mempunyai prestasi belajar lebih baik dibandingkan siswa dengan disposisi matematis sedang maupun rendah, siswa dengan disposisi matematis sedang mempunyai prestasi belajar lebih baik dibandingkan siswa dengan disposisi matematis rendah. Pada model pembelajaran langsung, siswa dengan disposisi matematis tinggi mempunyai prestasi belajar yang lebih baik

\section{DAFTAR PUSTAKA}

Akinsola, M.K. and Olowojaiye, F.B. 2008. "Teacher Instructional Methods and Student Attitude towards Mathematics". International Electronic Journal of dibandingkan siswa dengan disposisi matematis sedang dan rendah, siswa dengan disposisi matematis sedang dan rendah mempunyai prestasi belajar yang sama, 4) Pada masing-masing disposisi matematis siswa (tinggi, sedang dan rendah) antara model pembelajaran kooperatif tipe TPS dengan pendekatan open-ended dan pembelajaran langsung memberikan prestasi belajar yang sama pada materi bangun ruang sisi datar.

Berdasarkan simpulan, dikemukakan beberapa saran yaitu bagi kepala sekolah hendaknya senantiasa memberikan motivasi, monitoring dan evaluasi kepada para guru dan bagi guru matematika yaitu hendaknya termotivasi untuk menerapkan model pembelajaran yang inovatif seperti model pembelajaran kooperatif tipe TPS dengan pendekatan open-ended. Guru hendaknya memperhatikan faktor lain dari dalam diri siswa yaitu disposisi matematis siswa, karena dalam penelitian ini disposisi matematis siswa memberikan pengaruh terhadap prestasi belajar siswa.

Mathematics Education, 3(1): 6073.

Alfiyatul Fajar. 2010. Eksperimentasi Metode Pembelajaran TeamsGames-Tournament Dan Think- 
Pair-Share Pada Bab Bangun Ruang Prisma Tegak Dan Limas Ditinjau Dari Kecerdasan Intelektual (IQ) Siswa Kelas VIII Semester 2 SMP Se-Surakarta. Tesis: UNS Surakarta.

Anita Lie. 2004. Cooperative Learning: Mempraktekkan Cooperative Learning di Ruang-Ruang Kelas. Jakarta: PT.Gransindo

George, P.G. 2010. "The Effectiveness of Cooperative Learning Strategies in Multicultural University Classroom". Journal on Excellence in College Teaching, 5 (1): 21-30.

Hollingworth, L., Beard, J., and Proctor, T. 2007. "An Investigation of Item Type in a Standards-Based Assessment". International Journal of Practical Assessment, Bowering, M., Britget, M.L., and Michael, H. 2007. "Opening up Thinking Reflections on Group Work in a Bilingual Postgraduate Program". International Journal of Teaching and Learning in Higher Education. 19(1): 77-83.

Damon, W. 2005. "Personality Test: The dispositional dispute in teacher preparation today, and what to do about it". Journal of Teacher Education Issues on Dispositions. 2(3): 1-6.

Danebeth, T.G. 2012. "Think-Pair Share: Its Effect On the Academic Performance of ESL Students". International Journal of Literature, Linguistics \& Interdisciplinary Studies. 1(3): 22-

Mutia. 2013. Eksperimentasi Pembelajaran Matematika dengan Model Eliciting Activities (MEAs) dan Kooperatif Tipe Team Assisted Individualizaton (TAI) Ditinjau Dari Disposisi Matematis Siswa Kelas VII Se-Kota Bengkulu Pada 26. 
Materi Bangun Datar. Tesis: UNS

Surakarta.

Nohda, N. 2000. "Learning and Teaching Through Open-ended Approacrh Method. Dalam Tadao Nakahara dan Masataka Koyama (editor)". Proceeding of the $24^{\text {th }}$ of the Intenational Group for the Psychology of Mathematics Education. Hiroshima: Hiroshima University.

Ofodu, G.O. \& Raheem, A.L. 2011. "Cooperative Instructional Strategies and Performance Levels of Students in Reading Comprehension". International Journal Education Science. 3(2): 103-107.

Peker, M. 2008. "Pre-Service Teachers' Teaching Anxiety about Mathematics and Their Learning Style". Eurasia Journal of Mathematics, Science \& Technology Education. 5(4): 335345.

Permendiknas. 2006. Standar Isi. [Online]. Tersedia: http://www.kemdiknas.go.id/list_li nk/produk- hukum/peraturanmenteri/2006

November 2013].

Shimada, S. \& Becker, J. P. 1997. The open-ended approach: A new proposal for teaching mathematics. Reston, Virginia: National Council of Teachers of Mathematics.

Sumarmo U. 2010. Berfikir dan Disposisi Matematik: Apa. Mengapa, dan Bagaimana Dikembangkan pada Peserta Didik. [Online]. Tersedia: http://dc594.4shared.com/ [25 Mei 2013].

Zakaria, E. 2010. "The Effects of Cooperative Learning on Students' Mathematics Achievement and Attitude towards Mathematics". Journal of Social Sciences. 6(2): 272-275. 